\title{
Photosynthetic responses of UIva lactuca at very low light
}

\author{
Kaj Sand-Jensen* \\ Freshwater Biological Laboratory, University of Copenhagen, Helsingørsgade 51, DK-3400 Hillerød, Denmark
}

\begin{abstract}
Changes in photosynthetic variables and dark respiration were measured in Ulva lactuca acclimated to continuous photon flux densities between 0 and $55 \mu \mathrm{mol} \mathrm{m} \mathrm{m}^{-2} \mathrm{~s}^{-1}$ at $7^{\circ} \mathrm{C}$ for up to $80 \mathrm{~d}$. Photosynthetic light harvesting efficiency $(\alpha)$ was highest in $U$. lactuca acclimated to intermediate light levels of 8.8 and $25 \mu \mathrm{mol} \mathrm{m} \mathrm{m}^{-2} \mathrm{~s}^{-1}$ and was associated with maximum chlorophyll density and light absorptance. Below $2.5 \mu \mathrm{mol} \mathrm{m} \mathrm{m}^{-2} \mathrm{~s}^{-1}$, energy capture was insufficient to maintain the maximum light harvesting apparatus and at $55 \mu \mathrm{mol} \mathrm{m}^{-2} \mathrm{~s}^{-1}$, light was no longer fully limiting to photosynthesis. The light harvesting efficiency $(\alpha)$ was linearly related to light absorptance (A). The quantum efficiency $\left(\varnothing_{\mathrm{m}}=\alpha \mathrm{A}^{-1}\right)$ was, therefore, relatively constant and independent of the light acclimation level $(0.045$ to $0.059 \mathrm{~mol} \mathrm{C}$ [mol photon absorbed ${ }^{-1}$ ). The light compensation point for photosynthesis $\left(\mathrm{I}_{\mathrm{c}}\right)$ is given by the ratio between dark respiration $(r)$ and light harvesting efficiency $(\alpha)$. Dark respiration rates increased with incident light level. As a result of combined changes in $r$ and $\alpha, I_{c}$ had minimum values (1.5 to $2.3 \mu \mathrm{mol} \mathrm{m} \mathrm{m}^{-2} \mathrm{~s}^{-1}$ ) in plants acclimated to $8.8 \mu \mathrm{mol} \mathrm{m} \mathrm{m}^{-2} \mathrm{~s}^{-1}$ and it increased in the dark and particulariy in the high light acclimated plants $\left(5.3\right.$ to $\left.7.6 \mu \mathrm{mol} \mathrm{m} \mathrm{m}^{-2} \mathrm{~s}^{-1}\right)$. Photosynthetic capacity $\left(\mathrm{P}_{\mathrm{m}}\right)$ was linearly related to light harvesting efficiency $(\alpha)$, suggesting that photoadaptation mainly occurred by changes in number of photosynthetic units. U. lactuca growing in continuous low light possessed a photosynthetic capacity in excess of photosynthetic performance and would benefit from short-term exposure to high light. This may be of selective advantage, considering that natural light levels are widely fluctuating.
\end{abstract}

\section{INTRODUCTION}

Photoadaptive strategies have mainly been examined in terrestrial higher plants and aquatic unicellular algae (reviewed by Falkowski 1980, Björkman 1981, Richardson et al. 1983). Cellular responses to variations in incident light levels are numerous and include changes in (1) pigment concentrations, (2) ratio of light-harvesting pigments to reaction centres, (3) concentrations of components of electron transport chains, (4) carboxylating enzyme activities, (5) photosynthetic rates, (6) dark respiration rates, and (7) overall biochemical composition (Björkman 1981, Geider et al. 1985). The principle of adaptation to low light is to achieve a high efficiency of light absorptance by photosynthetic pigments and conversion into chemical energy with the minimum of tissue investment and operational costs. Among the responses above it would,

- Present address: Botanical Institute, University of Aarhus, Nordlandsvej 68, DK-8240 Risskov, Denmark therefore, be essential to keep absorptance and then usually pigment content high (1) and dark respiration rates low (6). Considering that light harvesting is the rate-limiting step it would seem logical, if possible, to reduce dark respiration rates by reducing the electron transport capacity (3) and carboxylating enzyme activity (4) relative to light absorptance (Björkman 1981, p. 85). This may create problems, however, with the physical arrangement of components in the thylakoid membranes serving the photosynthetic process and with the efficiency of energy transfer between lightharvesting pigments, reaction centres and catalyzers of electron transport. Furthermore, it would reduce the ability of the plant to utilize sudden improvements in the light availability, which is important considering that the natural light regime is always fluctuating on a diurnal and day to day basis.

The principles of cellular responses to varying light are the same within terrestrial higher plants and unicellular algae, but the respective role of each response for optimizing photosynthesis and growth differs both 
between the 2 groups and among different species. Increasing pigment content with reduced light, for example, appears to be a widespread response. However, the fractional absorptance of light increases more with increasing content of light-harvesting pigments in the unicells (Raven 1984) and is more important for their photosynthesis than it is for leaves of terrestrial plants, where areal chlorophyll density and package effects are high and absorptance less variable (Björkman 1981). Morphological changes, on the other hand, are mainly confined to higher plants and are very important for their light acclimation (e.g. canopy structure, leaf thickness and shape, shoot/root ratio; Björkman 1981).

Photoadaptation has been much less intensively investigated among aquatic macroalgae and angiosperms. However, the available information indicates that similar principles operate and that different submerged macrophyte species cover the range of responses found in unicells and terrestrial leaves (Spence \& Chrystal 1970a, b, Ramus et al. 1977. Sand-Jensen 1978). This is reasonable, considering their intermediate position with respect to taxonomy, anatomy and morphology. The range of responses, for example, is illustrated for light absorptance within the green marine macroalgae. The 2 cell-layer thick translucent thallus of Ulva spp. has an absorptance between 0.2 and 0.6 depending on pigment concentration whereas absorptance approaches 1.0 and is independent of pigment concentration in the 3 to $4 \mathrm{~mm}$ thick dark green thallus of Codium fragile (Ramus 1978).

With these ideas in mind I wanted to examine the effect of light acclimation on the photosynthetic apparatus of Ulva lactuca L. Since the ecological question underlying the experiments was 'What happens to U. lactuca at low light and low temperature in the field from autumn to spring?', I grew U. lactuca for extended periods at $7{ }^{\circ} \mathrm{C}$ and incident light levels from zero to $55 \mu \mathrm{mol} \mathrm{m}{ }^{-2} \mathrm{~s}^{-1}$ to include the responses both below and above the light compensation point for growth. My main objective was to determine the changes in chlorophyll density, light absorptance, photosynthetic capacity, quantum efficiency, and dark respiration rate and evaluate the respective role of these variables in regulating the efficiency of light utilization and the light compensation point for photosynthesis of U. lactuca.

\section{MATERIALS AND METHODS}

Circular Ulva lactuca discs were grown in filtered, nutrient enriched seawater at $7^{\circ} \mathrm{C}$ under continuous illumination from fluorescent lamps at 7 incident photon flux densities $(0,0.28,0.83,2.5,8.8,25$ and $55 \mu \mathrm{mol} \mathrm{m} \mathrm{m}^{-2} \mathrm{~s}$ ', PAR, 400 to $700 \mathrm{~nm}$ ) as described in the companion article (Sand-Jensen 1988). After accli- mation to a given incident light level, discs were taken for determination of dark respiration and photosynthesis at incident light levels ranging from 1.5 to $92 \mu \mathrm{mol} \mathrm{m}^{-2} \mathrm{~s}^{-1}$. In the first series of measurements, after $35 \mathrm{~d}$ of acclimation, photosynthesis and respiration were measured by exchange of inorganic carbon. In the second series, after 70 to $80 \mathrm{~d}$, oxygen exchange was measured. The 2 types of experiments were carried out for the purpose of comparison. Furthermore, the carbon exchange experiments were directly comparable to growth experiments in carbon units. The oxygen experiments were of shorter duration and could be performed at more incident light levels and give a

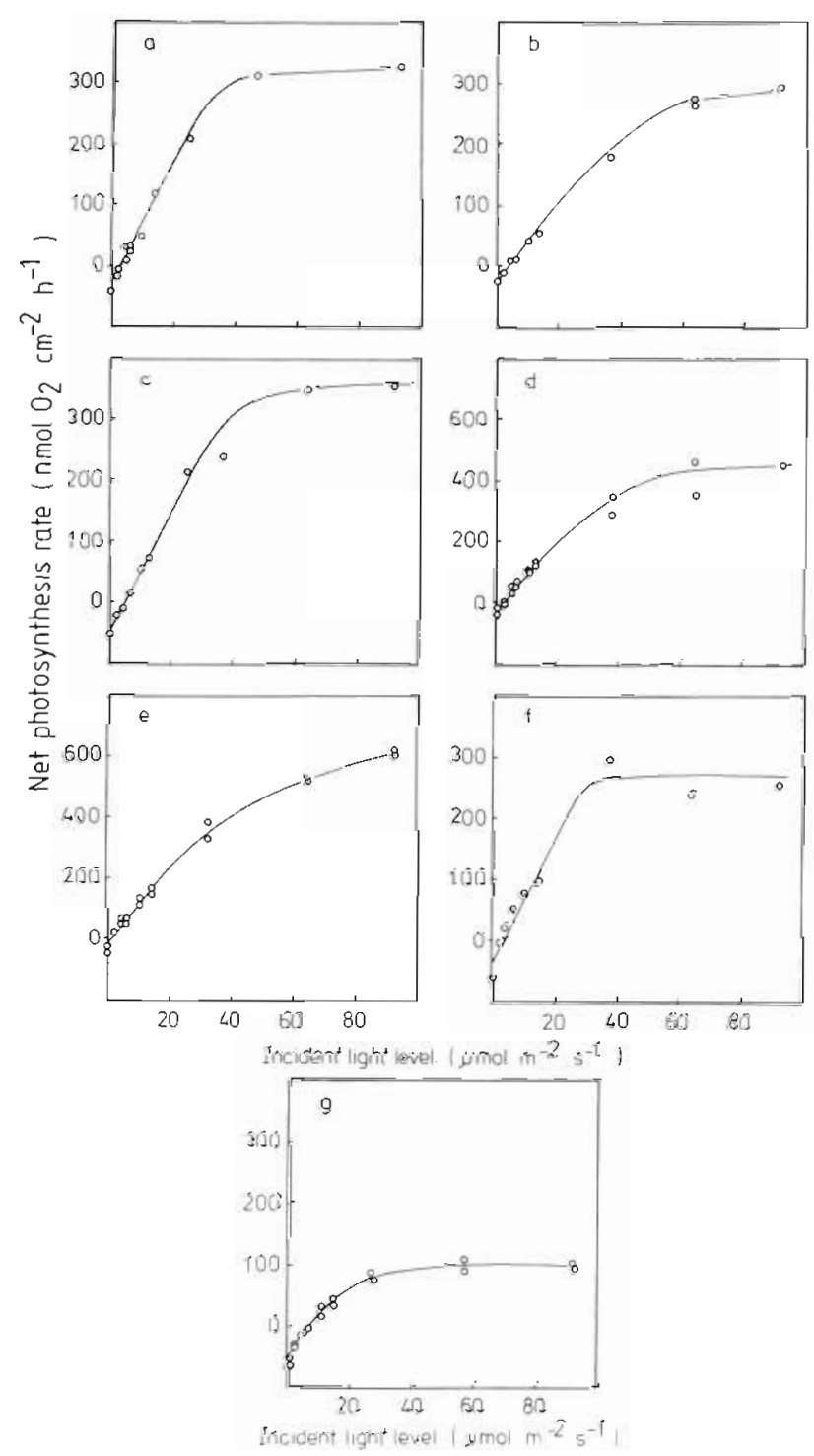

Fig. 1 Ulva lactuca. Photosynthesis-light curves at $7^{\circ} \mathrm{C}$ measured after 70 to $80 \mathrm{~d}$ of acclimation to incident light levels of (a) zero, (b) 0.3 , (c) 0.8 , (d) 2.5, (e) 8.8. (f) 25 and (g) 55 umol $\mathrm{m}^{-2} \mathrm{~s}^{-1}$ Net photosynthesis is shown as a function of incident light for every level of acclimation 
more complete description of the photosynthesis-light response curve. All measurements were in duplicate and photosynthetic experiments were done with the same light source at the same temperature, and in the same water as during growth. The water was aerated before experiments to achieve carbon dioxide and oxygen equilibrium with the atmosphere.

Carbon exchange was measured with single Ulva lactuca discs by following changes in dissolved inorganic carbon (DIC) in closed glass bottles (ca $30 \mathrm{ml}$ ) mounted on a rotating wheel in a thermostated incubator as previously described (Vermaat \& SandJensen 1987).

Oxygen exchange experiments were done in a small cylindrical photosynthetic chamber $(8 \mathrm{ml})$ with a flat top and bottom $1.5 \mathrm{~cm}$ apart (Kier et al. 1976). The chamber was illuminated from above and contained 1 Ulva lactuca disc facing the light source. The chamber was surrounded by a water jacket of thermostated water and had a temperature transducer, a fastresponse Clark-type oxygen electrode and a small hole for renewal of water mounted in the sides. A perspex magnetic stirring device was inserted from the bottom. The plant was separated from the stirrer by a small net. Oxygen changes were kept within $\pm 20 \%$ of atmospheric equilibrium. Oxygen registrations and calibrations were as described by Sand-Jensen (1983).

All experiments were initiated in the dark and proceeded at gradually higher light levels. The incident light levels were determined by placing a $2 \pi$ quantum sensor in the position of the discs either within the incubation bottles in carbon exchange experiments or within the oxygen chamber. Chlorophyll content and light absorptance were measured as previously described (Vermaat \& Sand-Jensen 1987) except that absorptance was expressed as fractional instead of percent absorptance.

\section{RESULTS}

The photosynthesis-light curves of Ulva lactuca, measured as oxygen exchange after 70 to $80 \mathrm{~d}$ of acclimation to different incident photon flux densities, are shown in Fig. 1. All curves showed an initial linear response between photosynthesis and light up to $15 \mu \mathrm{mol} \mathrm{m} \mathrm{m}^{-2} \mathrm{~s}^{-1}$ and saturation of photosynthesis at higher light levels between $30 \mu \mathrm{mol} \mathrm{m} \mathrm{m}^{-2} \mathrm{~s}^{-1}$ (f) and ca $100 \mu \mathrm{mol} \mathrm{m} \mathrm{m}^{-2} \mathrm{~s}^{-1}$ (e). Depending on acclimation, there were profound changes in the initial linear slope $(\alpha)$ of the $P$ vs I response, the light compensation point $\left(I_{c}\right)$, and the light-saturated net photosynthetic capacity $\left(\mathrm{P}_{\mathrm{m}}\right)$. To facilitate comparison, mean values of these photosynthetic variables, with confidence limits calculated by linear regression of $\mathrm{P}$ vs I for $\alpha$ and $\mathrm{I}_{\mathrm{c}}$, as well as quantum efficiency $\left(\varnothing_{\mathrm{m}}\right)$ and light absorptance (A), are shown separately as a function of light acclimation level (Figs. 2 and 3). The carbon exchange experiments after $35 \mathrm{~d}$ are shown in Fig. 2 and oxygen exchange experiments after 70 to $80 \mathrm{~d}$ in Fig. 3.

Fractional absorptance was lower after 70 to $80 \mathrm{~d}$ than $35 \mathrm{~d}$ at 25 and $55 \mu \mathrm{mol} \mathrm{m} \mathrm{m}^{-2} \mathrm{~s}^{-1}$. Absorptance was highest at intermediate light levels of 8.8 to $25 \mu \mathrm{mol}$ $\mathrm{m}^{-2} \mathrm{~s}^{-1}$ after $35 \mathrm{~d}$ and $8.8 \mu \mathrm{mol} \mathrm{m} \mathrm{m}^{-2} \mathrm{~s}^{-1}$ after $70 \mathrm{~d}$. The latter value was 1.8-fold higher than absorptance in the dark. Absorptance was 0.34 in the initial Ulva lactuca material and decreased gradually with time in plants

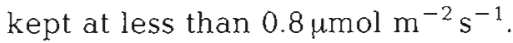

Fractional absorptance increased with the content of chlorophyll per unit of surface area. The rate of

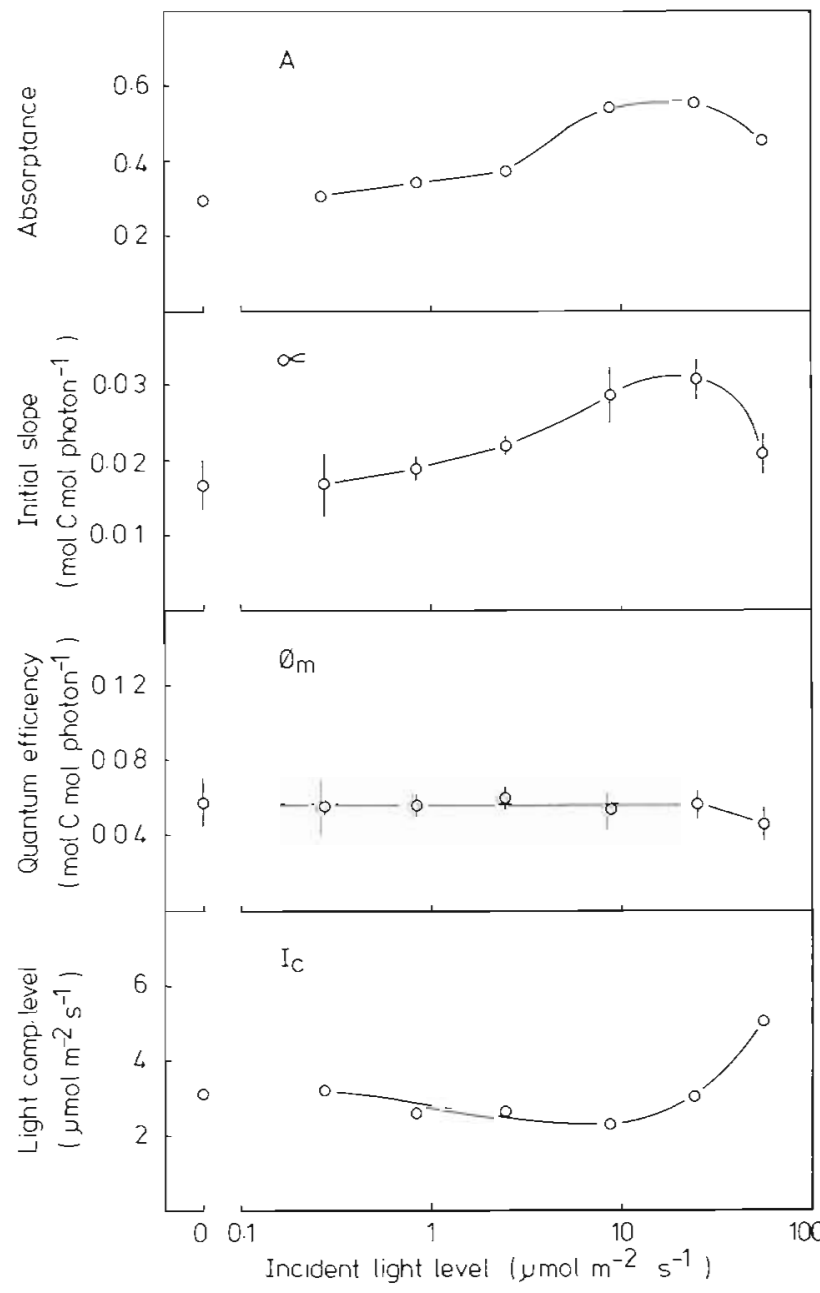

Fig. 2. Ulva lactuca. Photosynthetic characteristics after $35 \mathrm{~d}$ of acclimation to different light levels. Horizontal axis shows the incident photon flux density of the acclimation period. A: Fractional light absorptance; $\alpha$ : initial slope of the P vs I response; $\varnothing_{\mathrm{m}}$ : quantum efficiency; $\mathrm{I}_{\mathrm{c}}$ : light compensation point. Mean values are shown with $95 \%$ CL when possible. Photosynthetic measurements were based upon carbon exchange 
increase in absorptance became gradually smaller as the pigment content increased (cf. Ramus 1978). Absorbance $\left(=\log _{10}(1-A)^{-1}\right)$, on the other hand, was linearly related to chlorophyll density (Fig. 4). The regression line had a slope corresponding to $0.017 \mathrm{~cm}^{2}$

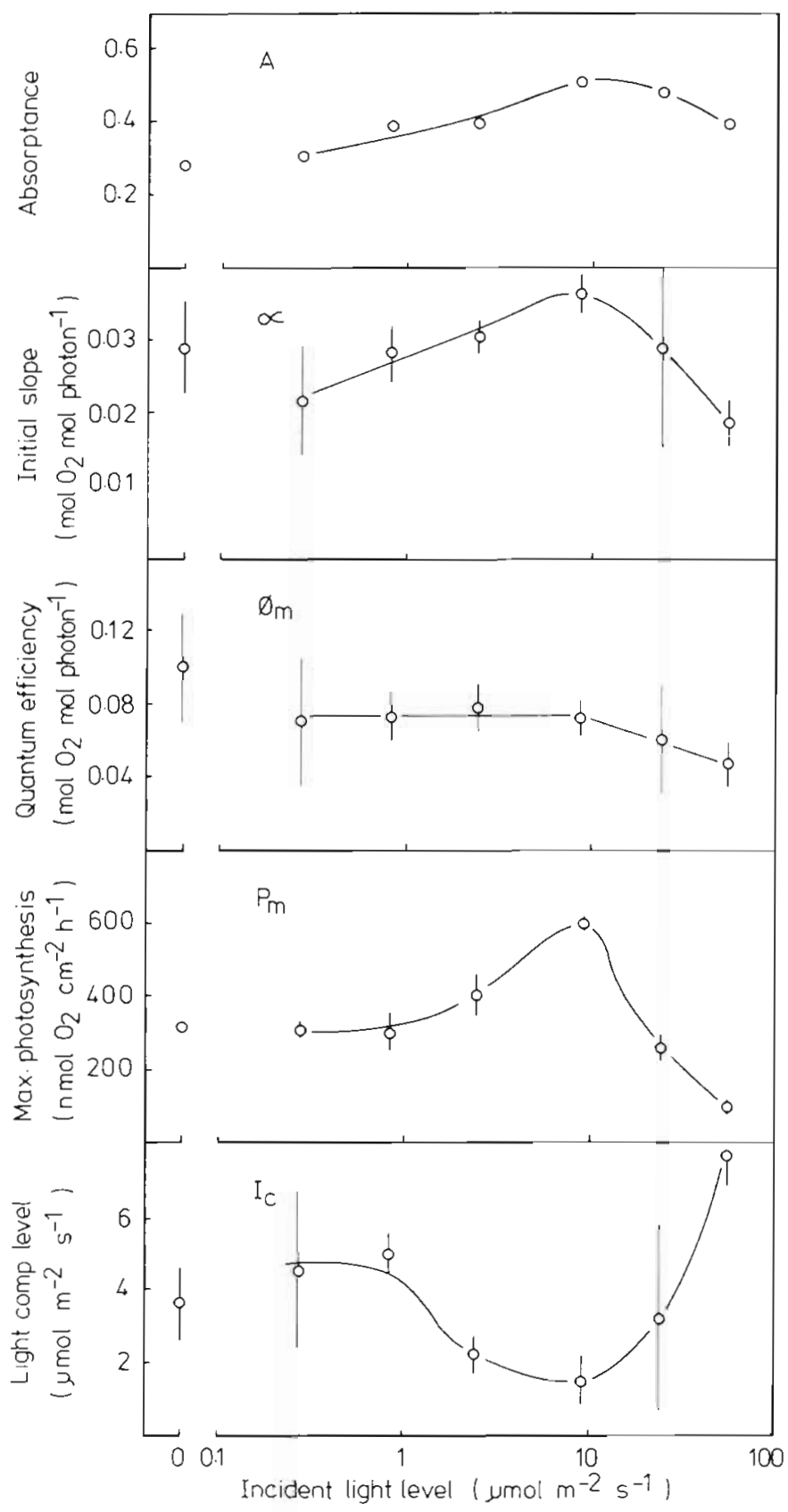

Fig. 3. Ulva lactuca. Photosynthetic characteristics after 70 to $80 \mathrm{~d}$ of acclimation to different light levels. Horizontal axis shows the incident photon flux density of the acclimation period. A: Fractional light absorptance; $\alpha$ : initial slope of the $\mathrm{P}$ vs I response; $\varnothing_{m}$ : quantum efficiency; $P_{m}$ : maximum net photosynthetic rate; $I_{c}$ : light compensation point. Mean values are shown with $95 \% \mathrm{CL}$ when possible. Photosynthetic measurements were based upon oxygen exchange
( $\mu \mathrm{g}$ chlorophyll $a+b)^{-1}$ as an average for the 400 to $700 \mathrm{~nm}$ spectrum of the light source. There was a positive intercept at zero chlorophyll, indicating a background absorbance in non-pigment tissue of ca 0.058 (ca 0.1 of fractional absorptance).

The initial slope $(\alpha)$ of the $P$ vs I response is a measure of the efficiency of utilization of available photons (mol $\mathrm{C}$ or $\mathrm{O}_{2}$ per mol incident photon). The initial slope followed changes in absorptance $A$ (Figs. 2 and 3). The initial slope $\alpha$ is shown for the carbon exchange experiments (molc [mol incident photons ${ }^{-1}$ ) as a function of absorptance (Fig. 5). The 2 variables were linearly related, indicating that quantum efficiency $\left(\varnothing_{\mathrm{m}}=\alpha \mathrm{A}^{-1}\right)$ was constant $(0.051 \pm$

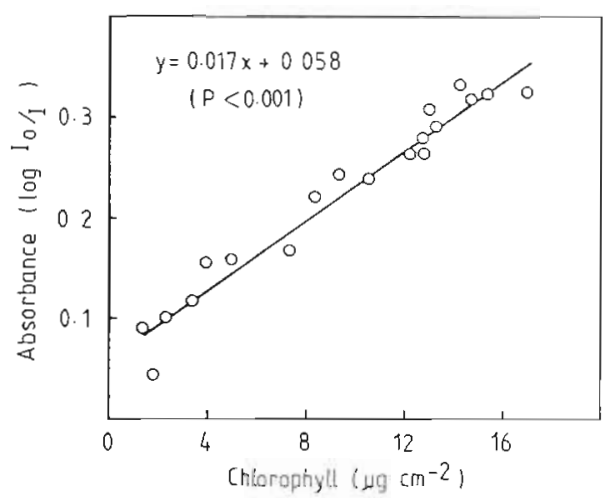

Fig. 4. Ulva lactuca Light absorbance as a function of chlorophyll density. Absorbance is defined as $\log _{10} \mathrm{I}_{0} / \mathrm{I}$ where $I_{0}$ and $I$ are incident and transmitted photon flux densities, respectively

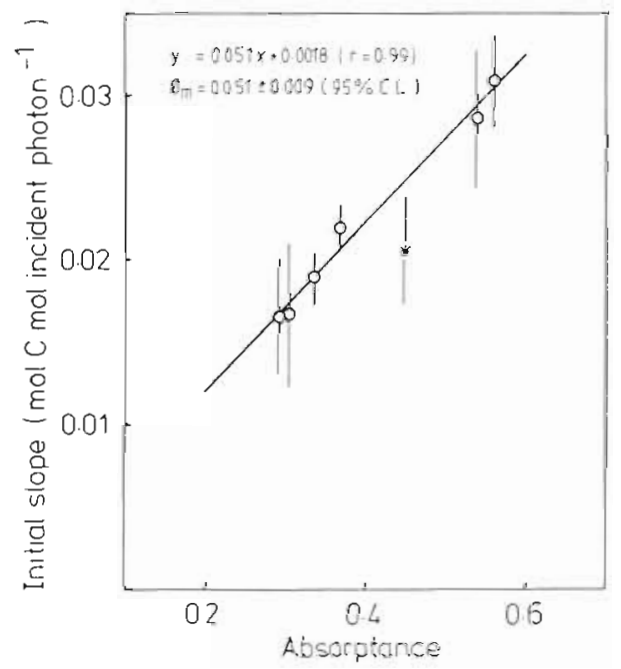

Fig. 5. Ulva lactuca. Mean initial slope $(\alpha)$ of the P vs I response $( \pm 95 \% \mathrm{CL})$ as a function of mean fractional absorptance (A) in plants acclimated for $35 \mathrm{~d}$ to different incident light levels. The linear slope of the $\alpha$ vs A relation (omitting 55 umol $\mathrm{m}^{-2} \mathrm{~s}^{-1}$ indicated by an asterisk) was equivalent to a mean quantum efficiency $\left(\varnothing_{\mathrm{m}}\right)$ of $0.051 \pm 0.009( \pm 95 \% \mathrm{CL})$ $\mathrm{molC}$ (mol photon absorbed) ${ }^{-1}$ 
Table 1. Ulva lactuca. Dark respiratory rates $\left(\mathrm{nmol} \mathrm{C} \mathrm{cm}^{-2} \mathrm{~h}^{-1}\right.$ ) measured after $35 \mathrm{~d}$ of acclimation to different incident light levels at $7^{\circ} \mathrm{C}$. Mean $\pm \mathrm{SD}(n=2)$

\begin{tabular}{cccccccc}
\hline & & \multicolumn{4}{c}{ Incident light acclimation level $\left(\mu \mathrm{mol} \mathrm{m}{ }^{-2} \mathrm{~s}^{-1}\right)$} & & \\
0 & 0.28 & & 0.83 & 2.48 & 8.80 & 24.75 & 55.0 \\
\hline $18.8 \pm 0.1$ & $19.7 \pm 1.0$ & $17.2 \pm 3.1$ & $20.4 \pm 2.7$ & $24.1 \pm 2.6$ & $33.8 \pm 1.9$ & $39.0 \pm 8.6$ \\
\hline
\end{tabular}

$\left.0.009(95 \% \mathrm{CL}) \mathrm{mol} \mathrm{C}[\mathrm{mol} \text { absorbed photons }]^{-1}\right)$ and independent of acclimation. There was a tendency, though not significant, for $\alpha$ at the highest light acclimation level of $55 \mu \mathrm{mol} \mathrm{m} \mathrm{m}^{-2} \mathrm{~s}^{-1}$ to fall below the line describing the relationship of $\alpha$ to $A$. The direct plot of $\varnothing_{\mathrm{m}}$ vs acclimation level also showed constant $\varnothing_{\mathrm{m}}$ values in the oxygen experiments after 70 to $80 \mathrm{~d}$, again with a tendency to decrease in high light (Fig. 3).

The photosynthetic capacity $\left(\mathrm{P}_{\mathrm{m}}\right)$ was positively related to the initial slope (Fig. 6) and showed maximum values at intermediate light levels (Fig. 3). The decline of $\mathrm{P}_{\mathrm{m}}$ in high light was particularly pronounced after 70 to $80 \mathrm{~d}$ in Ulva lactuca acclimated to $55 \mu \mathrm{mol}$ $\mathrm{m}^{-2} \mathrm{~s}^{-1}$ (Fig. 3).

The light compensation point of photosynthesis $\left(I_{C}\right)$ is given by the ratio of dark respiration ( $r$ ) to the initial slope $(\alpha)$ of the $\mathrm{P}$ vs I response. Dark respiration rates decreased from the values in high light acclimated plants to 2-fold lower rates in low light acclimated plants, when measured in carbon exchange experiments over $18 \mathrm{~h}$ (Table 1 ). The same tendency was observed in oxygen experiments but with much less reproducibility possibly due to too short duration of the experiments (<30 min; Fig. 1$)$. The initial slope was highest at intermediate light acclimation levels as

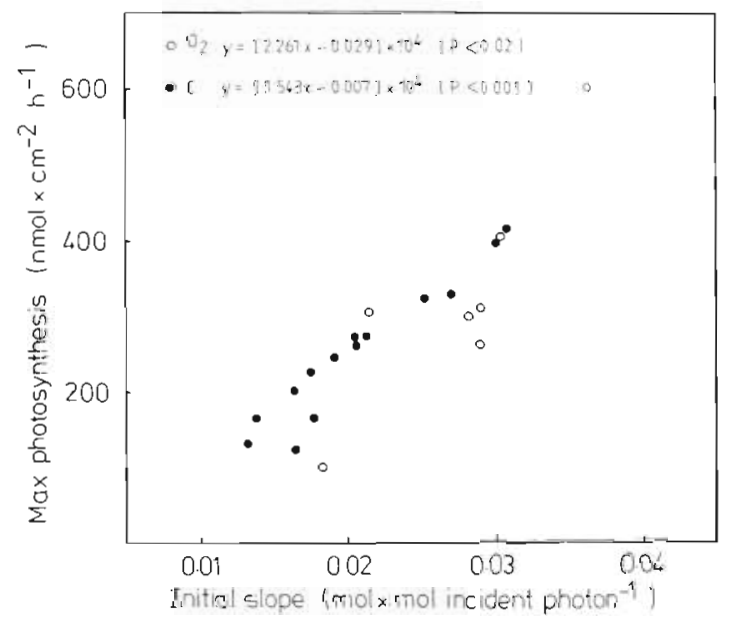

Fig. 6. Ulva lactuca. Relation between photosynthetic capacity $\left(P_{m}\right)$ and initial slope $(\alpha)$ of the P vs I for plants acclimated to different incident light levels for $35 \mathrm{~d}$ ( $\bullet$, carbon exchange experiments) or 70 to 80 days $(0$, oxygen exchange experiments) already emphasized (Figs. 2 and 3). As a combined effect of the changes in $\alpha$ and $\mathrm{r}, \mathrm{I}_{\mathrm{C}}$ had minimum values 11.5 to $2.3 \mu \mathrm{mol} \mathrm{m}{ }^{-2} \mathrm{~s}^{-1}$ in plants acclimated to $8.8 \mu \mathrm{mol}$ $\mathrm{m}^{-2} \mathrm{~s}^{-1}$ and higher values both in the dark and particularly in the high light acclimated plants (Figs. 2 and 3 ).

\section{DISCUSSION}

\section{Optimum light level for shade adaptation}

Growth experiments, conducted in parallel with the photosynthetic experiments, showed that the growth rate of Ulva lactuca increased with incident light (Sand-Jensen 1988). Maximum efficiencies of light utilization for growth, however, occurred at intermediate light levels corresponding to the region of optimum photosynthetic performance. Thus, absorptance and photosynthetic efficiency were highest at 8.8 and $25 \mu \mathrm{mol} \mathrm{m} \mathrm{m}^{-2}$ after $35 \mathrm{~d}$ and $8.8 \mu \mathrm{mol}$ after 70 to $80 \mathrm{~d}$, and the light compensation point was lowest at $8.8 \mu \mathrm{mol}$ $\mathrm{m}^{-2} \mathrm{~s}^{-1}$. A similar type of response was described for unicellular algae by Falkowski (1980).

The optimum light utilization of Ulva lactuca at 8.8 $\mu \mathrm{mol} \mathrm{m} \mathrm{m}^{-2} \mathrm{~s}^{-1}$ is photoadaptive in the sense that growth rates were much greater than anticipated from the initial slope of the P vs I response of plants acclimated to $55 \mu \mathrm{mol} \mathrm{m} \mathrm{m}^{-2} \mathrm{~s}^{-1}$. At incident light levels of $0.8 \mu \mathrm{mol}$ $\mathrm{m}^{-2} \mathrm{~s}^{-1}$ or less, light is below the compensation point and $U$. lactuca loses weight (Sand-Jensen 1988), and pigmentation, and absorptance and photosynthetic efficiency decline. It is noteworthy that the light compensation point for growth (ca $2.5 \mu \mathrm{mol} \mathrm{m} \mathrm{m}^{-2} \mathrm{~s}^{-1}$; SandJensen 1988) and the minimum light compensation points for photosynthesis ( 1.5 to $2.3 \mu \mathrm{mol} \mathrm{m} \mathrm{m}^{-2} \mathrm{~s}^{-1}$ ) are close to each other and significantly below $8.8 \mu \mathrm{mol}$ $\mathrm{m}^{-2} \mathrm{~s}^{-1}$, suggesting that a certain photosynthetic surplus of organic carbon is needed to attain maximum light-harvesting efficiency.

Photosynthesis of Ulva lactuca was saturated by light at $55 \mu \mathrm{mol} \mathrm{m} \mathrm{m}^{-2} \mathrm{~s}^{-1}$ in plants acclimated to this incident light level whereas light absorptance, initial slope and photosynthetic capacity were low. This may indicate a certain adverse effect of light at $55 \mu \mathrm{mol} \mathrm{m} \mathrm{m}^{-2} \mathrm{~s}^{-1}$ when supplied continuously at low temperature of $7^{\circ} \mathrm{C}$. A similar response in continuous light at $10^{\circ} \mathrm{C}$ was 
previously reported for U. lactuca (Vermaat \& SandJensen 1987). Apart from a tendency for quantum efficiency to decline in high light, however, there were no indications of photoinhibitory effects. Photoinhibition of oxygen evolution was not observed in any of the short-term experiments with Ulva lactuca exposed to $92 \mathrm{umol} \mathrm{m} \mathrm{m}^{-2} \mathrm{~s}^{-1}$ and is usually not anticipated either at such low incident light levels as $55 \mu \mathrm{mol} \mathrm{m} \mathrm{m}^{-2} \mathrm{~s}^{-1}$, even though some examples exist (Richardson et al. 1983).

In a recent paper, Raven (1984) made a cost-benefit analysis of photon absorptance of unicellular algae in low light. His thoughts are also relevant to the regulation of chlorophyll density in Ulva lactuca. The main principles are that photosynthetic energy is needed to produce the light-harvesting machinery (pigment and associated proteins and membranes). Benefits of additional light-harvesting machinery will depend on photon absorption, and thus on internal self-shading (package effects) and incident light levels. It is intuitively clear that algae in a saturating high light environment can benefit from a reduced pigment content by reducing the risks of photoinhibition and the costs of investment and repair of pigments, particularly because the growth rate is high and repair is expected to increase with pigment content and light level. On the other hand, in an extreme low-light environment, where growth is close to zero, small investments in light-harvesting machinery over extended periods will always be a benefit to microalgae and $U$. lactuca as long as only investment costs (Raven 1984) and not running costs are included. If we take the running costs (e.g. chlorophyll turn-over) into account, however, we will predict: (1) a light-dependent optimum level for chlorophyll in U. lactuca and, (2) depending on the balance between investment and running costs, a certain intermediate light level where chlorophyll densities are highest. Overall, these simple predictions agree with the actual observations. To perform a complete quantitative cost-benefit analysis, however, is still not possible.

\section{Relationship between photoadaptive variables}

A large photosynthetic efficiency and a small light compensation point are particularly important for successful plant growth in low light and several variables are involved in their regulation. The photosynthetic efficiency in low light $(\alpha)$ of Ulva lactuca acclimated to different light levels was linearly correlated to light absorptance (A) which in turn was regulated by changes in chlorophyll content. Close coupling between $\alpha$ and $\mathrm{A}$ has frequently been reported in different plant groups (Gabrielsen 1960, Geider et al. 1985, Lüning \& Dring 1985, Morel et al. 1987) and is anticipated if the quantum efficiency $\left(\varnothing_{\mathrm{m}}\right)$ is constant (i.e. $\alpha=\emptyset_{\mathrm{m}}$ A). The quantum efficiency appeared to be constant except for the non-significant decrease in high light acclimated plants. Furthermore, it is possible that the apparent decline of $\varnothing_{\mathrm{m}}$ in high light acclimated plants, if real, was due to an increased light absorptance by non-light-harvesting elements (e.g. carotenoids) in proportion to absorptance by chlorophylls which declined at high light.

The quantum efficiency of Ulva lactuca ranged from

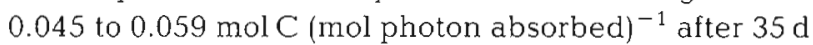
of acclimation and from 0.047 to $0.078 \mathrm{~mol} \mathrm{O}_{2}$ (mol photon) $)^{-1}$ after 70 to $80 \mathrm{~d}$. The somewhat higher efficiencies of oxygen evolution relative to carbon fixation corresponded to a photosynthetic quotient of 1.2 to 1.3 and are expected, considering a mixed nitrogen supply of ammonium and nitrate with possible preference for ammonium for growth. The quantum efficiency corresponded to the majority of results for unicellular algae (Bannister \& Weidemann 1984) and terrestrial leaves (Björkman 1981). I acknowledge, however, that considerable uncertainty and several possible errors are notoriously connected with estimates of $\varnothing_{\mathrm{m}}$ for all plants. For $U$. lactuca there were mainly problems with precise measurements and definitions of the relevant incident light field during both acclimation and experiments.

The light compensation point for photosynthesis $\left(I_{c}\right)$ is regulated by the same variables as above and, in addition, by dark respiration rates (r) (i.e. $\mathrm{I}_{\mathrm{c}}=\mathrm{r} \varnothing_{\mathrm{m}}{ }^{-1}$ $\left.\mathrm{A}^{-1}\right)$. Depending on light acclimation, $\mathrm{I}_{c}$ varied severalfold particularly due to changes in $\mathrm{r}$ (2-fold) and $A$ (almost 2-fold). These results stress the major influence of $r$ and $A$ (and thus chlorophyll content) for successful photosynthetic performance and growth in very weak light.

Evaluation of different strategies of photoadaptation, based upon changes in the P vs I curve as a function of light acclimation, has frequently been attempted, but is not straightforward (reviewed by Richardson et al. 1983). Several types of curves are present, their form changes with the units of expressing $P$, and predictions of underlying mechanisms suffer from the lack of measurements of light-harvesting capacity, rate-limiting steps for light-saturated photosynthesis, capacities for electron transport and carboxylation, etc. The response of Ulva lactuca is characterized by a positive relationship between light saturated photosynthesis $\left(\mathrm{P}_{\mathrm{m}}\right)$ and the initial slope of P vs $I(\alpha)$. This response resembles that described by Prézelin (1981), indicating shade adaptation by increases in the number of photosynthetic units with a 'fixed' relationship between light-harvesting chlorophylls, reaction centres and reaction centres I and II.

The positive relationship between $\mathrm{P}_{\mathrm{m}}$ and $\alpha$ ensured 
that photosynthetic capacity of Ulva lactuca was in excess of photosynthetic performance at all light acclimation levels, except at $55 \mu \mathrm{mol} \mathrm{m}^{-2} \mathrm{~s}^{-1}$. U. lactuca growing in low light would, therefore, benefit from short-term exposure to higher light by enhanced photosynthetic rates. $U$. lactuca is usually most common under well-illuminated conditions in shallow water, but a high biomass may also be found under low light conditions at considerable depths (Sand-Jensen unpubl.). Because of its free-floating form, movements occur between shallow and deep water. Furthermore, extensive daily and seasonal changes in surface light occur. Accordingly, the observed response to light acclimation is perhaps more beneficial than shade responses which involve increased pigmentation, but reduced photosynthetic capacity, and thus reduced ability to utilize and tolerate high light exposure.

Acknowledgements. I thank Dr O. Gertz-Hansen, T. Kana, T. V Madsen and M. Dring and an anonymous reviewer for comments on the manuscript and B. Brandt and B. Christensen for typing. This work was partially supported by The Danish Natural Science Research Council, The Carlsberg Foundation, and The Danish Agency for Environmental Protection.

\section{LITERATURE CITED}

Bannister, T. T., Weidemann, A. D. (1984). The maximum quantum yield of phytoplankton photosynthesis in situ. J. Plankton Res. 6: 275-294

Björkman, O. (1981). Responses to different quantum flux densities. In: Lange, O. L., Nobel, P. S., Osmond, C. B., Ziegler, H. (eds.) Encyclopedia of plant physiology, Vol. 12A, Physiological plant ecology, I, Responses to the physical environment. Springer-Verlag, Berlin, p. 57-107

Falkowski, P. G. (1980). Light-shade adaptation in marine phytoplankton. In: Falkowski, P. G. (ed.) Primary productivity in the sea. Plenum Press, New York, p. 99-119

Gabrielsen, E. K. (1960). Beleuchtungsstärke und Photosynthese. In: Ruhland, W. (ed.) Encyclopedia of plant physiology, Vol. V/2. Springer-Verlag, Berlin, p. 22-47

Geider, R. J., Osborn, B. A., Raven, J. A. (1985). Light depend- ence of growth and photosynthesis in Phaeodactylum tricornutum (Bacillariophyceae). J. Phycol. 21: 609-619

Kier, F., Allermann, K., Floto, F., Olsen, J., Sortkær, O. (1976). Changes of exponential growth rates in relation to differentiation of Geotrichum candidum in submerged culture. Physiol. Plant. 38: 6-12

Lüning, K., Dring, M. J. (1985). Action spectra and spectral quantum yield of photosynthesis in marine macroalgae with thin and thick thalli. Mar Biol. 87: 119-129

Morel, A., Lazzara, L., Gostan, J. (1987). Growth rate and quantum yield time response for a diatom to changing irradiances (energy and colour). Limnol. Oceanogr. 32: 1066-1084

Prézelin, B. B. (1981). Light reactions in photosynthesis. In: Platt, $\Upsilon$ (ed.) Physiological bases of phytoplankton ecology. Can. Bull. Fish. Aquat. Sci. 210: 1-46

Ramus, J. (1978). Seaweed anatomy and photosynthetic performance: the ecological significance of light guides, heterogeneous absorption and multiple scatter. J. Phycol. 14: 352-362

Ramus, J., Lemons, F., Zimmerman, C. (1977). Adaptation of light-harvesting pigments to downwelling light and the consequent photosynthetic performance of the eulittoral rockweeds Ascophyllum nodosum and Fucus vesiculosus. Mar, Biol. 42: 893-903

Raven, J. A. (1984). A cost-benefit analysis of photon absorption by photosynthetic unicells. New Phytol. 98: 593-625

Richardson, K., Beardall, J., Raven, J. A. (1983). Adaptation of unicellular algae to irradiance: an analysis of strategies. New Phytol. 93: 157-191

Sand-Jensen, K. (1978). Metabolic adaptation and vertical zonation of Littorella uniflora (L.) Aschers and Isoetes lacustris L. Aquat. Bot.: 1-10

Sand-Jensen, K. (1983). Photosynthetic carbon sources of stream macrophytes. J. exp Bot. 34: 198-210

Sand-Jensen, K. (1988). Minimum light requirements for growth in Ulva lactuca. Mar. Ecol. Prog. Ser. 50: 187-193

Spence, D. H. N., Chrystal, J. (1970a). Photosynthesis and zonation of freshwater macrophytes. I. Depth distribution and shade tolerance. New Phytol. 69: 205-215

Spence, D. H. N., Chrystal, J. (1970b). Photosynthesis and zonation of freshwater macrophytes. II. Adaptability of species of deep and shallow water New Phytol. 69 $217-227$

Vermaat, J. E., Sand-Jensen, K. (1987). Survival, metabolism and growth of Ulva lactuca L. under winter conditions: a laboratory study of bottlenecks in the life cycle. Mar Biol. 95: 55-61 